\title{
Regstellende aksies ten opsigte van die natuurwetenskappe
}

In die huidige oorgangstyd van 'n samelewing gedomineer deur apartheid na 'n veelrassige, demokratiese bestel, word die beginsel van regstellende aksies wyd gedebatteer. Talle skrywers en politici is eens omtrent die noodsaaklikheid van regstellende aksies wat primêr gerig is op die swart gemeenskap wat in die verlede om verskeje redes gelyke toegang tot geleenthede in feitlik alle sektore van die samelewing ontsê is. In die Suid-Afrikaanse konteks moet die primêre doel van sodanige aksies wees om diegene teenoor wie deur apartheidswetgewing gediskrimineer is, in staat te stel om ten volle en op alle vlakke in 'n toekomstige demokratiese bestel te kan presteer. Regstellende aksies is dus deur en deur 'n middel tot 'n doel en 'n tussentydse maatreël om 'n ten volle geïntegreerde veelrassige demokrasie met volledig gelyke geleenthede te verwesenlik.

Die afskaffing van diskriminerende wetgewing en die totstandkoming van 'n Handves vir Menseregte is essensiële stappe om regstellende aksies te realiseer, maar is nie voldoende om gelyke geleenthede vir almal te verseker nie. Bykomende maatreëls, wat nie alleenlik gemik is op gelykheid of gelyke geleenthede nie, maar ook die historiese agterstand moet aanspreek wat vanweë diskriminerende wetgewing ontstaan het, moet geïmplementeer word. By implikasie sal deur regstellende aksies die soeklig op alle instellings en strukture van ons samelewing val, en sodoende ook ons almal op die een of ander manier raak.

Die agterstand van swartes in ons samelewing is veral geaksentueer in die natuurwetenskappe en tegnologie juis daardie dissiplines wat mense in staat stel om deur innovasie en entrepreneurskap nywerhede te stig, werk te verskaf en ekonomiese groei teweeg te bring. Die rede hiervoor is 'n onderwyssisteem gepaard met inperkende wetgewing wat aanleiding gegee het tot die feitlik totale uitsluiting van swartes in die wetenskap- en tegnologiearena van die land; waar slegs 1 uit elke 10000 swart skoolbeginners standerd 10 slaag met universiteitstoelating en met wiskunde en wetenskap as kwalifiserende vakke; waar slegs sowat $5 \%$ van die graduandi in natuurwetenskap en ingenieurswese uit ons swart gemeenskappe kom; en waar meer as $65 \%$ van die wetenskaponderwysers in sekondêre skole oor geen toepaslike nasekondêre opleiding beskik nie.

Bykomstige faktore wat beperkend inwerk op ekonomiese groei en welvaartskepping, is eerstens die ondervoorsiening van menslike hulpbronne met toepaslike natuurwetenskaplike en tegnologiese kwalifikasies vir 'n land soos Suid-Afrika met sy uiters voordelige bedeling van natuurlike hulpbronne; en tweedens die wanbalans wat in die universiteite en technikons se voorsiening van menslike hulpbronne in die natuurwetenskaplike en tegnologiese vakrigtings ontwikkel het. Lande met suksesvolle industrialiseringstrategieë produseer ewe veel, of waarskynlik meer, ingenieurs as wetenskaplikes (in vergelyking met 'n verhouding van 1:4 in Suid-Afrika) en heelwat meer tegnies gekwalifiseerdes as ingenieurs (in Suid-Afrika daarenteen is die verhouding ongeveer $1: 1$ ). As daar verder in aanmerking geneem word dat in SuidAfrika slegs een ingenieur per dertig duisend van die bevolking opgelei word in vergelyking met syfers van tot 10 per dertig duisend van die bevolking in geïndustrialiseerde lande, dan is dit duidelik dat die opleiding van ingenieurs en tegnies gekwalifiseerdes nie ten koste van die natuurwetenskappe mag plaasvind nie.

Die krisis rondom wiskunde- en wetenskaponderrig, veral in swart skole, behoort die hoogste prioriteit in 'n program van regstellende aksies te geniet, aangesien dit 'n sneeubaleffek kan hê op die implementering van ander sodanige aksies. Regstellings ten opsigte van die onderrig van hierdie vakke op skool sal "n verhoogde vloei van swart skoliere na die wetenskaplike en tegnologiese studierigtings op universiteite en technikons bewerkstellig en 'n ideale geleentheid bied om verdere regstellings te bewerkstellig, soos ten opsigte van die wanbalans in die opleiding van ingenieurs en wetenskaplikes en tegnici. Sodanige aksies sal verseker dat die swart gemeenskap vinniger in staat gestel word om by te dra tot, en die voordele te geniet van, tegnologiese ontwikkeling en ekonomiese groei in die land.

Talle inisiatiewe is reeds met groot sukses deur niestaatsorganisasies met behulp van finansiële ondersteuning deur die privaat sektor en buitelandse bronne van stapel gestuur om die leemtes veral in die wetenskapen wiskundeonderrig in swart skole aan te spreek en remediërende en regstellende aksies aan universiteite te loods. Pogings in skole is in die verlede egter belemmer deur die verset van die owerhede om hierdie inisiatiewe te ondersteun. Vanweë bogenoemde behoeftes het die SNO, wie se opdrag dit is om die gebalanseerde voorsiening van menslike hulpbronne en kundigheid in die natuurwetenskappe en tegnologie te verseker ten einde aan die behoeftes van die land te voldoen, ook verskeie aksies van stapel gestuur. Aksies op pretersiêre vlak is veral gerig op die opleiding van wetenskaponderwysers, innoverende en kreatiewe wetenskaponderwys en -navorsing en die gebruik van multimediaonderwystegnologie. Op tersiêre vlak is die universiteiteontwikkelingsprogram ingestel, 'n regstellende aksieprogram wat daarop gemik is om aan die personeel en studente van die histories swart universiteite die geleentheid te bied om hulle kennis en kundigheid dermate te verbeter dat hulle in 'n kompeterende omgewing kan presteer. Programme word ontwerp en geloods in noue oorleg met en volgens die behoefte van die onderskeie instansies, en sluit 'n wye reeks aktiwiteite in, gerig op opleiding en opheffing ter stimulering van 
personeelontwikkeling, studenteondersteuning en dies meer.

Dit is voor die hand liggend dat die proses om gelyke geleenthede op natuurwetenskaplike en tegnologiese gebied vir almal te bewerkstellig, baie lank sal duur. Dié proses sou wel bespoedig kon word deur aksies gerig daarop om die breë publiek en die ouergemeenskap in die besonder bewus te maak van die belang van natuurwetenskap en wiskunde as noodsaaklike onderbou op skool veral indien ons die vakbonde en burgerlike verenigings hierby sou kon betrek.
Bogenoemde aksies om opleidingsprogramme in die natuurwetenskappe en tegnologie, asook kundighede en vaardighede aan agtergeblewe gemeenskappe te bied ten einde hulle toe te rus om in 'n kompeterende samelewing te kan meeding, is 'n uiters belangrike faset van regstellende inisiatiewe. Daar is heelwat ander, maar nie een hiervan kan die gewenste resultate oplewer nie, tensy hulle gepaard sou gaan met 'n verandering in ons waardes en in ons persepsies van mekaar, waardeur 'n sosiale klimaat en omgewing geskep word wat eerbied en vreedsame naasbestaan in die hand werk.

G. VON GRUENEWALDT

Stigting vir Navorsingsontwikkeling

\section{Eenheid in die wetenskap, 'n wetenskapstaal en Afrikaans as wetenskapstaal}

'n Wetenskapstaal omvat breër begrippe as woordelyste en terminologie, terwyl die groei en besig van 'n taal as wetenskapstaal ook nie net 'n kwessie van woordelyste en terminologie is nie - die werklike vraagstuk lê myns insiens baie dieper. Ek wil eers net die vraagstuk van 'n taal as wetenskapstaal beskou, en dan terugkeer na Afrikaans.

Die taal wat in ' $n$ groep of in 'n samelewing gebesig word, is baie nou verweef met die hele kultuurbesit van die groep of samelewing. Een van die dele van die kultuurbesit van dié bepaalde samelewing is die manier waarop die wetenskap beleef word en 'n deel vorm van die kultuur van hierdie samelewing. Hierdie belewenis strek vanaf 'n a-wetenskaplike samelewing - waar niks oor die wetenskap in die kultuurbesit gevind word nie - tot by 'n volledig wetenskaplike samelewing, waar die wetenskap as geheel in die kultuurbesit geabsorbeer is. Vanuit hierdie beskouing is dit dus vanselfsprekend dat die mate waarin wetenskap as kultuurelement van die samelewing geld, ook bepalend sal wees vir die mate waarin wetenskap in die taal sal neerslag vind.

In hierdie verband is dit ook nodig om iets meer te sê oor wat ek onder die begrip wetenskap verstaan. Wetenskap is nie slegs die kennisversameling wat deur al die verskillende vakwetenskappe gevorm word nie, maar omvat ook die begrippe en denke aangaande die samehang van die vakwetenskappe binne die wetenskap as geheel. In "Die Wetenskap" word dus alle aspekte van die geesteswetenskap, natuurwetenskap en tegniese wetenskap in hulle karakteristieke vermenging binne die gespesialiseerde vakwetenskappe teruggevind, maar ook die verbindende wetenskapsleer.

Verder merk ek ook op dat die begrippe aangaande die wetenskap as geheel en die samehang van die gespesialiseerde vakwetenskappe, baie meer kultuurgebonde is, en baie moeiliker internasionaal oordraagbaar is, as die begrippe binne die gespesialiseerde vakwetenskappe. Hierdie toedrag van sake neig reeds om die groei in die vakwetenskappe sterker te bevorder as die groei in die oorkoepelende wetenskapsdenke. Die utiliteitswaarde van die vakwetenskappe in die moderne wêreld is vir elke samelewing wat sy lewensomstandighede wil verbeter (sy dit die oplos van maatskaplike probleme of die ontwikkeling van 'n beter vervaardigingsindustrie) ooglopend. Hierdie feit lei daartoe dat elke samelewing ook in sy eie belang die groei van die gespesialiseerde vakwetenskappe stimuleer. Dit kan dus baje maklik gebeur dat in 'n gegewe samelewing die wetenskap as kultuurelement verarm word tot die beoefening van bloot die gespesialiseerde vakwetenskappe vanweë die bostaande oorwegings. In hierdie toestand lyk dit vir my logies dat die behoefte aan 'n eie wetenskapstaal sal kwyn - aangesien die eng internasionaal gekoppelde vakwetenskappe uiteindelik ook bedien kan word met die gebruik van 'n taal wat in die vakwetenskaplike gemeenskap internasionaal as die beste kommunikasiemedium aanvaar word. Die gevolge vir veral klein samelewings en tale ten opsigte van die ontwikkeling, groei en instandhouding van 'n volledige wetenskapstaal is duidelik negatief.

Uit hierdie oorwegings lei ek altyd graag af dat die beginpunt vir ' $n$ wetenskapstaal binne elke samelewing met wetenskap as deel van sy kultuur die erkenning en beoefening van die "Eenheid in die Wetenskap" is. Aangesien dit nie kan geskied sonder die nodige vakwetenskaplike onderbou in die samelewing nie (die eenheid kan immers nie sonder die dele bestaan nie), is dit noodsaaklik dat daar ook ' $n$ basis van behoorlike vakwetenskaplike aktiwiteit binne die samelewing sal wees. Dit is hier waar terminologie en woordelyste ter sprake kom, want wanneer die vakwetenskappe in die taal van die samelewing beleef word, ontstaan uiteindelik ook 
'n toestand waarin die hele wetenskap as kultuurelement binne die samelewing beleef word. Dit gee die nodige stukrag vir die groei van die wetenskapstaal oor die hele veld.

Op hierdie stadium is dit goed om na Afrikaans as wetenskapstaal te kyk in die lig van die voorgaande. Ek wil volstaan met enkele opmerkings:

- Myns insiens word daar in Afrikaans veels te min gewerk oor die geheel van die wetenskap en byna geen aandag aan die samehang van die vakwetenskappe gegee nie. Leerstoele oor die geskiedenis en filosofie van die wetenskap is nie een van die prioriteite in ons Afrikaanse universiteitsgemeenskap nie.

- Ons kan tans krities vra of die Afrikaanse kultuur die dieptegang het om die begrippe van die geheel van die wetenskap en die eenheid in die wetenskap te hanteer, en waarom dit dan nie gebeur nie. As die "wetenskaplike" publikasies in Afrikaans ontleed word, vind 'n mens dit oorwegend vakwetenskaplik gerig. Dit kan dus terminologieskeppend wees, maar is nie volledig wetenskapstaalskeppend nie.

Die SA Tydskrif vir Natuurwetenskap en Tegnologie volgens my bostaande redenasie - kan juis oor die lang termyn tot die groei van Afrikaans as wetenskapstaal bydra deur te help om die denke oor die breë wetenskap in Afrikaans te publiseer. Die klem wat gelê word op vakwetenskaplike werk moet gebalanseer word met die nodige werk oor die samehang van al die gespesialiseerde vakwetenskappe wat die hele veld wat deur die Tydskrif hanteer word, dek. Die Tydskrif sal dus noodwendig ook ten minste 'n medium moet word vir die filosofie van die natuurwetenskappe en tegniese wetenskappe. Hierdie gebalanseerde poging sal dan lei tot die bevordering van Afrikaans as 'n wetenskapstaal.

- Die beste vir Afrikaans as wetenskapstaal sou een tydskrif vir wetenskap in Afrikaans wees. Hierin kan oor die breë wetenskap, asook oor die nodige spesialiswetenskappe as onderbou van die eersgenoemde, gewerk word.

Die tergende vraag bly egter - kan die Afrikaanse kultuur dit al doen - of dit nog steeds doen? 